\title{
Gustatory Innervation and bax- Dependent Caspase-2: Participants in the Life and Death Pathways of Mouse Taste Receptor Cells
}

\author{
QUN ZENG, ALICE KWAN, AND BRUCE OAKLEY* \\ Department of Biology, University of Michigan, Ann Arbor, Michigan 48109-1048
}

\begin{abstract}
In the adult mouse tongue, an average of $11 \%$ of the gustatory receptor cells are replaced each day. In investigating homeostatic cell death mechanisms in gustatory renewing epithelium, we observed that taste receptor cells were selectively immunopositive for the $b c l-2$ family death factor, Bax, and for the protease Caspase- $2^{\text {Nedd2/Ich } 1}$. We determined that $8-10 \%$ of the taste receptor cells of the vallate papilla were Bax positive and that $11 \%$ were Caspase-2 positive. Some of these immunopositive taste cells had apoptotic morphological defects. Within the subset of vallate taste cells immunopositive for either Caspase-2 or Bax, up to $79 \%$ coexpressed both death factors. Bax and Caspase-2 first appeared in occasional vallate taste receptor cells on the same postnatal day-the day after birth. bax null mutation markedly reduced gustatory Caspase-2 immunoexpression. These observations suggest that taste cell death pathways utilize p53, Bax, and Caspase-2 to dispose of aged receptor cells. Apart from reducing Caspase-2 expression, Bax deficiency also altered taste organ development. $b a x^{-1-}$ mice had a more profusely innervated vallate papilla, which grew to be $25 \%$ longer and taller, with the mean taste bud containing more than twice the normal number of taste cells. This augmentation of taste organ development with increased innervation is complementary to the well-documented reduction in taste organ development with sparse innervation. We propose that additional taste neurons survived programmed cell death in Bax-deficient mice, thereby providing an inductive boost to vallate gustatory development. J. Comp. Neurol. 424:640-650, 2000. ๑ 2000 Wiley-Liss, Inc.
\end{abstract}

Indexing terms: apoptosis; development; p53; programmed cell death; turnover; vallate papilla

Cell death is an important feature of organ development and tissue homeostasis. In renewing epithelia, new cells serve to replace old cells that have completed their lives (Ellis et al., 1991; McCall and Cohen, 1991; Haake and Polakowska, 1993; Polakowska et al., 1994; Tamada et al., 1994). Because taste buds are discrete packets of identifiable cells, their turnover presents an opportunity to investigate a discrete death pathway in a renewing epithelium in vivo. The turnover of mammalian taste receptor cells may engage one or more death and survival factors from the $b c l-2$ family that includes such survival genes as $b c l-2$ and $b c l-x_{L}$ (Boise et al., 1993; Reed, 1997; Adams and Corey, 1998), and death-promoting genes like bak and bax (Nuñez and Clarke, 1994; Chittenden et al., 1995; Kiefer et al., 1995). In selected apoptotic pathways, the bax gene is a probable target of the tumor suppressor protein p53, which kills cells that are crippled by irreparably damaged DNA (Farmer et al., 1992; Miyashita et al., 1994; Selva- kumaran et al., 1994; Yin et al., 1997; Miyashita and Reed, 1995). p53 also promotes cell death as part of the homeostatic turnover of postmitotic cells (Zeng and Oakley, 1999).

It is probable that Bax functions by perforating mitochondrial membranes to cause the release of procaspases into the cytoplasm, where they are activated (Susin et al., 1999). The presence of Bax in dying taste cells (Zeng and Oakley, 1999) suggested that an examination of bax null

Grant sponsor: NIH; Grant number: DC-00083; Grant sponsor: NSF; Grant number: DBI-9413211.

The first two authors contributed equally to this research.

*Correspondence to: Bruce Oakley, Department of Biology, 3127 Natural Science Building, University of Michigan, Ann Arbor, MI 48109-1048. E-mail: boakley@umich.edu

Received 23 August 1999; Revised 12 May 2000; Accepted 12 May 2000 
mutant mice (Krajewski et al., 1994) might help identify a downstream caspase.

Caspases are a family of at least 14 cysteine proteases that are mammalian relatives of the Caenorhabditis elegans death executor Ced-3 (Thornberry and Lazebnik, 1998). In the degradation phase of programmed cell death (PCD) all cells employ caspases ( $\mathrm{Li}$ and Yuan, 1999; Weil et al., 1999). Caspases degrade nuclear lamins, cytokeratins, and other proteins within dying cells (Kaufman et al., 1993; Neamati et al., 1994; Lazebnik et al., 1995; Caulin et al., 1997). The caspase of interest in the present report, Caspase- $2^{\text {Nedd } 2 / I c h 1}$, is strongly expressed during the embryonic period of maximal cell death in mouse liver, lung, kidney, small intestine, vibrissae follicles, and brain precursor cells-the source for Caspase-2's original isolation (Kumar et al., 1992, 1994). Functional Caspase-2 is required for the death of sympathetic neurons deprived of growth factor (Troy et al., 1997).

The neuron-like properties of adult taste cells raise the possibility that aged taste cells may die like neurons. However, most neurons arise from neuroectoderm and become permanent body constituents, whereas taste cells originate from local epithelium and undergo continual replacement, dying after an average life span of about 9 days in rat and mouse (Beidler and Smallman, 1965; Takeda, 1979; Farbman, 1980; Stone et al., 1995; Takeda et al., 1996). A recent examination of taste cell death pathways suggests that aged taste cells die apoptotically since they display morphologic apoptotic features such as marginated and condensed nuclear chromatin (pyknosis), shrunken cytoplasm, and membrane blebs (Zeng and Oakley, 1999). Furthermore, $8 \%$ of taste cells have fragmented DNA, and 8-10\% characteristically coexpress p53 and Bax, while not uncommonly also displaying membrane blebs.

By exploiting taste buds as quantifiable clusters of postmitotic, simple epithelial cells, the first objective of the present research was to find evidence for the involvement of a bax-dependent caspase in taste cell turnover. Attention was focused on the vallate papilla, a small mound located on the dorsal surface of the posterior third of the mouse tongue. In the vallate papilla we observed that Bax and Caspase-2 were exclusively localized to a subset of taste cells in which they were characteristically coexpressed. The additional finding that Caspase- 2 expression depends on bax makes Caspase-2 a probable downstream effector of Bax in the apoptotic pathway for vallate taste receptor cells.

The second objective of the present research was to examine gustatory development in the presence of increased innervation. It was known from neonatal denervation of the developing vallate epithelium in rats that taste bud development requires innervation (Hosley et al., 1987a,b). More recent evidence for the neural control of taste organ development has emerged from the association of sparse gustatory innervation with fewer taste buds and stunted gustatory papillae in trkB and brain-derived neurotrophic factor (BDNF) null mutant mice (Zhang et al., 1997)_observations soon confirmed by multiple studies (Nosrat et al., 1997; Fritzsch et al, 1997; Oakley et al., 1998; Cooper and Oakley, 1998; Liebl et al., 1999; Mistretta et al., 1999).

The strong positive correlations between innervation density and taste bud abundance $(r=0.96)$ and between innervation density and the area of the gustatory epithe- lium ( $\mathrm{r}=0.94)$ support the neural induction theory of taste organ development (Oakley et al., 1998). The nerve dependence of taste bud development is also evident when embryonic gustatory innervation is impaired either by injecting a neurotoxin (Morris-Wiman et al., 1999) or by exploiting ectopically expressed BDNF to intercept developing gustatory axons before they reach the tongue surface (Ringstedt et al., 1999). Each of these several studies of taste bud development represents a loss-of-function strategy.

The present study represents a gain-of-function strategy that exploits the increased gustatory innervation in bax null mutant mice. It had already been observed that several other types of sensory neurons were more abundant in $b a x^{-1-}$ mice, probably because sensory neurons had been spared programmed cell death (PCD) (Deckwerth et al., 1996; Shindler et al., 1997; White et al., 1998). Consequently, we hypothesized that bax null mutation would result in increased gustatory innervation and a corresponding enhancement of vallate gustatory development. We demonstrate herein that the heavily innervated $b a x^{-1-}$ vallate gustatory papilla was larger, and its taste buds contained more than twice as many taste receptor cells as wild-type controls. The most probable explanation is a gain-of-function in which increased gustatory innervation enhanced peripheral gustatory development.

\section{MATERIALS AND METHODS Animals and tissue preparation}

Two embryonic (E15 and E17), 12 postnatal (P0-P7), and 9 adult C57BL/6J mice were used as wild-type controls. The day of birth was considered postnatal day 0 (P0 = E19). Wild-type embryos and neonates were euthanized with carbon dioxide. Tongues from P1 bax null mutant mice ( $\left.b a x^{-1-}, n=4\right)$ and P1 bax heterozygous mice $\left(b a x^{-1-}, n=4\right)$ were provided by E. Johnson and S. Korsmeyer. Adult wild-type mice, $b a x^{-1-}$ mice aged 6 months and 8 months ( $\mathrm{n}=2$ and $\mathrm{n}=2$, respectively), and bax $x^{-1-}$ mice aged 8 and 10 months $(n=2$ and $n=1$, respectively), were anesthetized with sodium pentobarbital (50 mg/kg body weight i.p.). The mice were perfused with heparinized Ringer's solution followed by acidalcohol fixative (70\% ethanol, $10 \%$ acetic acid). All excised tongues were postfixed in the acid-alcohol solution for at least 12 hours. The adult $b a x^{-1-}$ and $b a x^{+/-}$mice were a gift of S. Korsmeyer (Knudson et al., 1995).

On the midline of the posterior third of the mouse tongue is a solitary vallate papilla enclosed by two rostrocaudally directed, shallow trenches whose walls at P7 contain more than 100 taste buds that increase in number to an asymptote of more than 120 buds by $3-4$ weeks (Cooper and Oakley, 1998). In determining the effects of bax deficiency on taste bud size, the use of a matching-bybracketing design made it possible to determine whether adult taste bud size also changed with age. Specifically, three wild-type mice aged 7 months were bracketed by two $b a x^{-1-}$ mice aged 6 months and two $b a x^{-1-}$ mice aged 8 months, yielding a bax ${ }^{-1-}$ group mean of 7 months. Data from a 4-month old wild-type mouse were included to extend the age range. The finding of gustatory organ enhancement in $b a x^{-/-}$mice prompted an examination of the three $b a x^{+/-}$mice (by then at 8, 8, and 10 months). Cryostat cross sections of the vallate papilla, made at a 
thickness of $10 \mu \mathrm{m}$, were immunostained as described below. The University of Michigan Committee on the Use and Care of Animals approved the animal research protocol.

\section{Immunocytochemistry}

Mounted tongue sections were rehydrated, treated with $3 \%$ normal goat serum for 30 minutes, followed by $0.3 \%$ hydrogen peroxide for 4 minutes, and incubated with the primary antibody for 1 hour at room temperature. A 45minute application of the biotinylated secondary antibody was followed by 30 minutes of treatment with the ABC avidin-biotin complex (PK-4000; Vector, Burlingame, CA) and 10 minutes with 3,3'-diaminobenzidine tetrahydrochloride (DAB; Sigma, St. Louis, MO). Three or four rinses with phosphate-buffered saline (PBS), $\mathrm{pH} 7.4$ separated each of these steps. Taste receptor cells were identified by staining for keratin 8 , one of five simple keratins that are useful markers for taste receptor (intragemmal) cells (Knapp et al., 1995). To count intragemmal cell nuclei, slides were stained for 10 minutes with $1 \mathrm{mM}$ bisbenzamide (Hoechst 33258; Sigma) and coverslipped with DPX (BDH, Poole, UK).

The antibodies used were as follows: Anti-keratin 8: 1:100-1:1400 dilutions of rat monoclonal antibody Troma-I (Hybridoma Bank, University of Iowa). Secondary antibody: 1:1500 biotinylated-sp-conjugated goat antirat IgG (Jackson Immunoresearch, West Grove, PA). Antibax: 1:100 anti-mouse Bax (rat IgM mAb; PharMingen, SanDiego, CA; Clone G206-1276). Secondary antibody: 1:100 biotinylated goat anti-rat IgM (Jackson Immunoresearch). Anti-Nedd2: 1:100 anti-mouse Nedd2 (Caspase2); rabbit polyclonal (SC-626; Santa Cruz Biotechnology, Santa Cruz, CA). Secondary antibody: 1:200 biotinylated goat anti-rabbit IgG (SC-2015; Santa Cruz). (Exposing the tissue sections to $1 \%$ trypsin for 5 minutes improved the Caspase-2 staining.) Anti-BrdU: 1:5 rat anti-5-bromo-2' deoxyuridine (Accurate Chemical and Scientific, Westbury, NY). Secondary antibody: 1:1500 biotinylated goat anti-rat IgG (Jackson Immunoresearch). RMO-270: 1:200 anti-neurofilament (gift of V. Lee, University of Pennsylvania School of Medicine). Secondary antibody: 1:200-500 biotinylated goat anti-rat IgG (Jackson Immunoresearch).

\section{Fluorescent double labeling for intragemmal cell Bax and Caspase-2 (Nedd2)}

Slides with tongue sections underwent sequential incubations for 1 hour with 1:100 anti-mouse Bax, 45 minutes with 1:100 biotinylated goat anti-rat IgM secondary antibody, 30 minutes with $1.5 \mu \mathrm{g} / \mathrm{ml}$ streptavidin-Texas Red (GIBCO BRL, Gaithersburg, MD), 60 minutes with 1:100 anti-mouse Nedd2, and 60 minutes with 1:100 fluorescein isothiocyanate (FITC)-conjugated goat anti-rabbit secondary antibody. Three PBS rinses were interspersed between each of these steps. Bax-positive cells were red, and Nedd2-positive cells were green. Omission of either the primary or secondary antibody eliminated this specific staining.

\section{Fluorescent double labeling for keratin 8 and nuclei to count intragemmal cell nuclear profiles}

The keratin 8 of intragemmal cells was revealed by staining with 1:100 Troma-I followed by 1:1500 biotinylated goat anti-rat secondary antibody and 1:100
streptavidin-Texas Red. Ten minutes in $1 \mathrm{mM}$ bisbenzamide colored the nuclei blue when visualized with optics suitable for fluorescence.

\section{Double labeling for keratin 8 and BrdU to compare the rate at which taste cells were added to wild-type and bax ${ }^{-1-}$ taste buds}

At 9 a.m., intraperitoneal injections of BrdU (Sigma) at $50 \mathrm{mg} / \mathrm{kg}$ body weight were given to four mice (two wildtype aged 7 months, one bax ${ }^{-1-}$ mouse aged 6 months, and one $b a x^{-1-}$ mouse aged 8 months). Three days after BrdU injection, the mice were euthanized at 9 a.m. and the tongues treated as described above. Ten-micrometerthick, mounted tongue sections were subjected to four 4-minute washes in PBS/TX-100 and DNA denaturation by $2 \mathrm{~N} \mathrm{HCl}$ for 30 minutes, followed by three 10-minute washes in PBS/TX-100. A 60-minute incubation with 1:5 anti-BrdU was followed by exposure to the secondary antibody, 1:1500 biotinylated goat anti-rat. After three 4-minute washes in PBS, the slides were treated with a 30-minute application of the $\mathrm{ABC}$ avidin-biotin complex and exposed to DAB/nickel chloride for 10 minutes. To visualize the intragemmal cells, 1:1400 Troma-I was applied followed by 1:1500 of the biotinylated goat anti-rat secondary antibody, the ABC avidin-biotin complex, and DAB. Three rinses with PBS occurred between each of these steps. BrdU-positive nuclei were dark blue, and the keratin 8-positive intragemmal cells were yellow-brown.

\section{Sucrose preference assay}

Pairs of adult wild-type mice and $b a x^{-/-}$mice were given continuous access to a bottle of sucrose and a bottle of distilled water (two-bottle preference test). Every 24 hours the solutions were interchanged in position, and every 48 hours the next stronger sucrose solution was substituted $(0.03,0.1$, and lastly $0.3 \mathrm{M}$ sucrose; each vs. distilled water). The sucrose preference threshold was defined as the lowest sucrose concentration to comprise $75 \%$ of the total fluid intake.

\section{Data analysis}

A taste bud with the modal diameter of 35-40 $\mu \mathrm{m}$ can be spanned by four $10-\mu \mathrm{m}$-thick sections. Each of the larger sections through a taste bud was defined as a taste bud profile. Within each taste bud profile Bax-positive or Caspase-2-positive taste cells were tabulated by counting each immunoreactive cell apex or cell base, provided it also included a nuclear profile. Isolated immunopositive apical or basal cell fragments were not counted. No correction was made for "split" cells or nuclei.

Vallate taste bud profiles contained a total of $27 \pm 4$ taste cells (mean $\pm 1 \mathrm{SD}$; Zeng and Oakley, 1999). The use of a constant factor, in this instance 27 cells per profile, enabled comparison of the relative incidence of Baxpositive and Caspase-2-positive intragemmal cells in the taste bud profiles of wild-type mice.

To quantify the relative increase of intragemmal cells in $b a x^{-1-}$ mice, we used bisbenzamide-stained $10-\mu \mathrm{m}$-thick sections in which counts of nuclear profiles were made from taste buds sectioned longitudinally, parallel to the major diameter of the elliptical nuclei. Had there been a marked increase in the minor nuclear diameter (nuclear thickness within the depth of the tissue section), it could have spuriously increased the counts of bax-deficient nuclear 

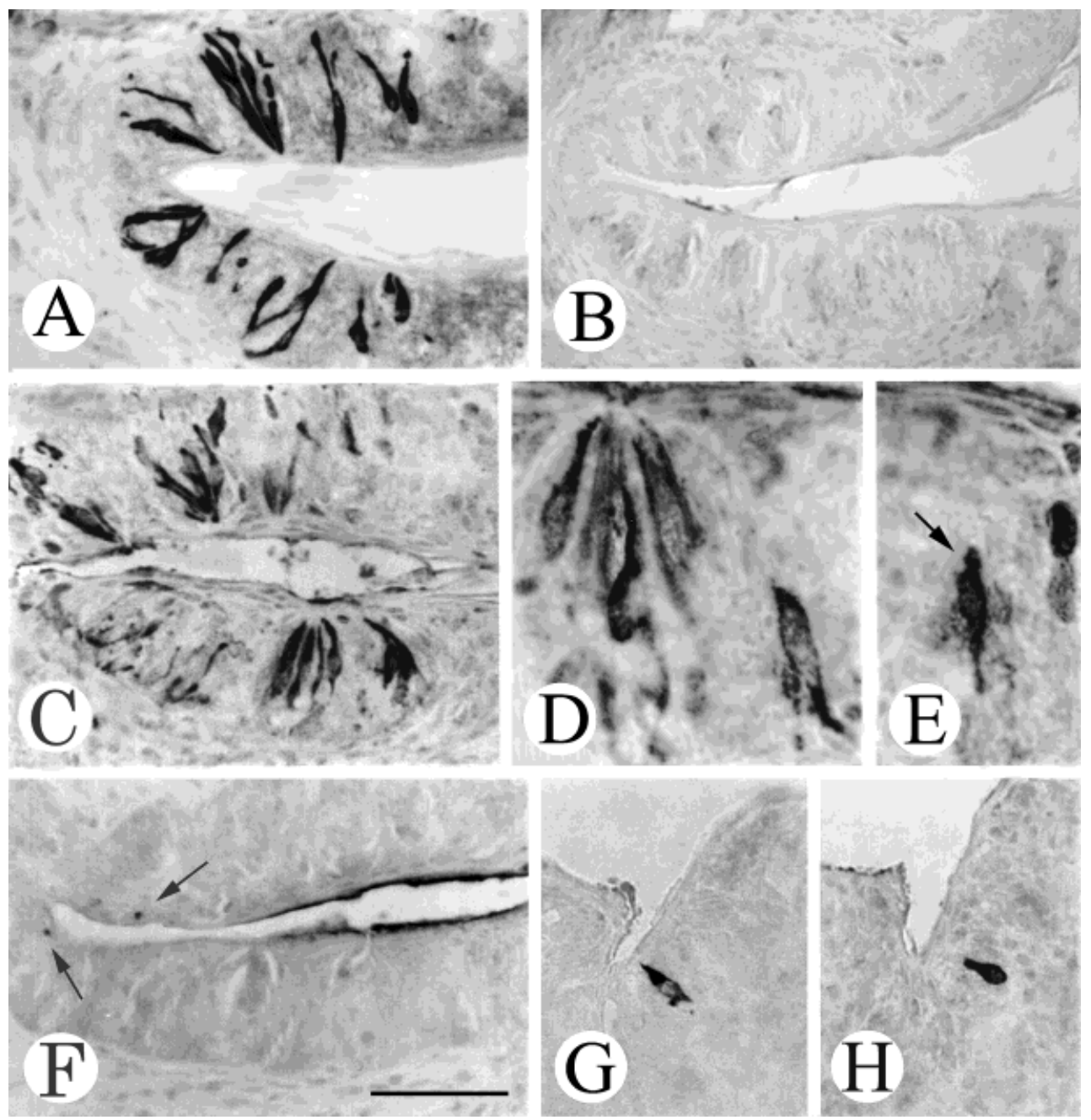

Fig. 1. A: Only a few taste cells were immunopositive for Bax in adult wild-type vallate taste buds. B: In Bax-deficient tissue there was no staining of taste cells with anti-Bax. C: As with Bax, Caspase-2 in the tongue was detected only in subsets of taste cells. D: Caspase-2 was in the cytoplasm of intragemmal cells that (E) were sometimes compacted and deformed (arrow). F: In Bax-deficient taste

profiles. However, $b a x^{-\prime-}$ mice had no significant increase in the minor nuclear diameter. The mean minor diameter \pm $1 \mathrm{SD}$ was $4.0 \pm 0.8 \mu \mathrm{m}$ for wild-type and $4.2 \pm 1.1 \mu \mathrm{m}$ for $b a x^{-\prime-}$ mice; $n=30$ nuclei each in two wild-type mice aged 7 months, and 30 nuclei each in one $b a x^{-1-}$ mouse aged 6 and one $b a x^{-1-}$ mouse aged 8 months.

For ease of communication, the terms "cell profiles" or "nuclear profiles" are sometimes abbreviated to "cells" or "nuclei," respectively.

Adobe PhotoShop was used to merge, normalize image density, and place labels on the panels in Figures 1-3.

\section{RESULTS}

\section{Bax and Caspase-2 immunoreactivity in adult and perinatal tongue}

In adult mouse tongue, keratin 8 was present only within cells of salivary ducts and within most, probably

buds, Caspase-2 staining was markedly reduced (arrows). G: This P1 vallate contained one Bax-positive cell, whereas an adjacent section (H) contained a different elongated Caspase-2-positive cell. Scale bar $=50 \mu \mathrm{m}$ in $\mathrm{A}, \mathrm{C} ; 80 \mu \mathrm{m}$ in $\mathrm{B} ; 21 \mu \mathrm{m}$ in D,E; $55 \mu \mathrm{m}$ in $\mathrm{F} ; 52 \mu \mathrm{m}$ in $\mathrm{G}, \mathrm{H}$

all, cells within taste buds. Figure 3A,C provides morphological overviews of the wild-type vallate papilla and its keratin-8-positive taste buds. Bax was restricted to a few elongated (intragemmal) taste cells (Fig. 1A). Bax was present in the cytoplasm of $10 \%$ of the adult vallate intragemmal cells (Zeng and Oakley, 1999). The absence of Bax staining in the vallate of $b a x^{-1-}$ mice established the specificity of the Bax antibody (Fig. 1B).

Undetected in adult squamous epithelium or in salivary glands and ducts, Caspase-2 immunoreactivity was limited to the region of taste buds, where it was present in $11 \%$ of adult intragemmal cells (Fig. 1C,D, Table 1). Most Caspase-2-positive taste cells looked normal, but some had apoptotic morphology such as cytoplasmic condensation or membrane blebbing (Fig. 1E).

At E15 and at E17 there were no Bax-positive cells in the serially sectioned vallate papilla. Nor were there Baxpositive, p53-positive, or Caspase-2-positive cells in the 
TABLE 1. Caspase-2 Immunoreactive Taste Bud Cells ${ }^{1}$

\begin{tabular}{ll}
\hline Parameter & Value \\
\hline No. of taste bud profiles examined & 304 \\
Total no. of Caspase-2-immunoreactive cells (range & 892 \\
of Caspase-2-immunoreactive cells/taste bud profile) & $(0-5)$ \\
Calculated no. of intragemmal cells in 304 taste bud profiles & 8,208 \\
Percentage of 8,208 intragemmal cells that were Caspase-2 & $11 \pm 0.8$ \\
immunoreactive $(n=4$ mice $)$ & \\
\hline
\end{tabular}

${ }^{1}$ Taste bud profiles of four adult wild-type mice aged 12-20 weeks were examined for Caspase-2-immunoreactive vallate taste cells. We counted each immunoreactive cell apex or base that also included a nuclear profile. [A vallate taste bud profile contains a mean of 27 intragemmal cells, as determined from counts of nuclear profiles in bisbenzamide-stained serial sections of a separate sample of 40 wild-type vallate taste buds (Zeng and Oakley, 1999).]
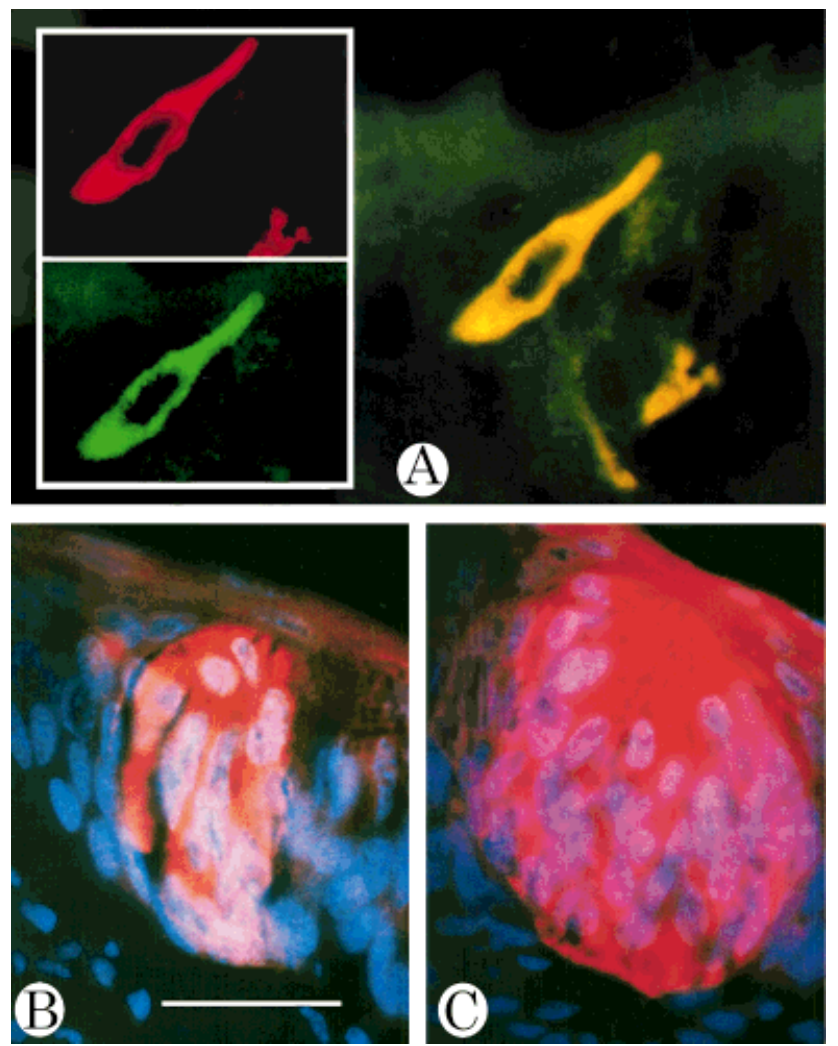

Fig. 2. A: This section through a P5 vallate papilla shows an intragemmal cell double labeled (gold) for Bax (red inset) and Caspase-2 (green inset). B,C: Double staining for intragemmal cell keratin 8 (red) and for nuclei (blue) permitted counts of adult vallate intragemmal nuclear profiles. Representative taste bud profiles of (B) a wild-type and (C) a bax ${ }^{-1-}$ mouse are shown. The trench wall is at the upper right. Scale bar $=22 \mu \mathrm{m}$ in A; $26 \mu \mathrm{m}$ in insets; $30 \mu \mathrm{m}$ in $\mathrm{B}, \mathrm{C}$.

vallate papilla at $\mathrm{P} 0$ when the vallate contains numerous immature taste cells and a mean of 18 taste buds having keratin 8-positive taste cells (present results; Cooper and Oakley, 1998; Zeng and Oakley, 1999). In day-by-day examinations from P0 to P7, vallate taste cells positive for Bax or Caspase-2 were first evident on P1 (Fig. 1G,H). In P1-P7 mice, the Caspase-2-positive intragemmal cells were elongated; in contrast, the basal cells were polygonal and Caspase-2 negative. Within the subset of vallate taste cells immunopositive for either Caspase- 2 or Bax, $79 \%$
TABLE 2. Coexpression of Bax and Caspase-2 in Taste Bud Cells ${ }^{1}$

\begin{tabular}{lcc}
\hline & \multicolumn{2}{c}{ Staining in the vallate gustatory epithelium } \\
\cline { 2 - 3 } & $\begin{array}{c}\text { Total no. of } \\
\text { immunostained } \\
\text { taste cells }\end{array}$ & $\begin{array}{c}\text { Selectively immunostained } \\
\text { cells as \% of the sum of all } \\
\text { immunostained taste cells }\end{array}$ \\
\hline P7 wild-type & & 8 \\
Bax only & 5 & 14 \\
Caspase-2 only & 9 & 79 \\
Bax and Caspase-2 & 52 & 100 \\
Sum & 66 & 14 \\
Adult wild-type & 26 & 22 \\
Bax only & 42 & 64 \\
Caspase-2 only & 120 & 100 \\
Bax and Caspase-2 & 188 & \\
Sum & & \\
\hline
\end{tabular}

${ }^{1}$ The incidence of vallate intragemmal cell profiles immunoreactive for Bax, for Caspase-2, and for both. Immunoreactive taste cell profiles were counted within 51 taste bud profiles of two adult mouse vallate papillae $(\approx 44$ taste buds $)$ and within the entire serially sectioned vallate papillae of two $\mathrm{P} 7$ mice $(\approx 108$ taste buds per vallate; entire serially sectioned vallat
Cooper and Oakley, 1998).

coexpressed both death factors at P7. Bax/Caspase-2 coexpression diminished to $64 \%$ in adults (Fig. 2A, Table 2).

\section{Caspase-2 expression in bax null mutant mice}

Bax-deficient vallate taste buds were examined in P1 and adult mice. In adults the absence of Bax substantially reduced, but did not wholly eliminate, Caspase-2 immunoreactivity (Fig. 1F). P1 $b a x^{-/-}, b a x^{+/-}$, or wild-type mice had 13-16 vallate taste buds that were examined for Caspase-2 expression with complete serial sections of the vallate. At P1 Caspase-2 was expressed in a total of six taste cells in a wild-type mouse, four taste cells in a $b a x^{+1-}$ mouse, and one taste cell in a $b a x^{-1-}$ mouse. Hence, in adults, and probably in $\mathrm{P} 1$ mice, inactivation of the bax gene reduced Caspase-2 expression.

\section{Taste cell abundance and the sizes of taste buds and taste cells}

In adult $b a x^{-1-}$ and $b a x^{+/-}$mice, the vallate taste buds were larger than those of wild-type controls. The two taste bud profiles indicated by arrows in Figure 3C and D had areas within $1 \%$ of the mean areas of wild-type and $b a x^{-1-}$ taste bud profiles, respectively. It was helpful to use keratin 8 staining to establish the lateral margins of each taste bud profile, both to outline the area of the taste bud profiles and to restrict counts of bisbenzamide-stained nuclear profiles to intragemmal cells (Fig. 2B,C). Figure 4 shows the mean areas of taste bud profiles for individual mice of the three genotypes. The mean taste bud profile area in bax knockout mice was markedly greater than in wild-type mice $(P<0.001, t$-test). A follow-up on this finding revealed that heterozygous mice had a mean vallate taste bud profile significantly larger than in wild-type mice $(P<0.05$, one-tailed $t$-test) and smaller than in knockout mice $(P<0.001$, one-tailed $t$-test $)$. Trends with age were small and inconsistent across genotype (Fig. 4). With genotype ignored, age alone accounted for less than $0.2 \%$ of the variance of the taste bud profile areas among these 10 mice.

The number of nuclear profiles per mean $b a x^{-1-}$ taste bud profile increased 1.7-fold. Assuming taste buds are approximately spherical, a 1.7-fold increase in mean cells per taste bud profile converts mathematically to a 2.5 -fold increase in the number of cells contained within a bax 

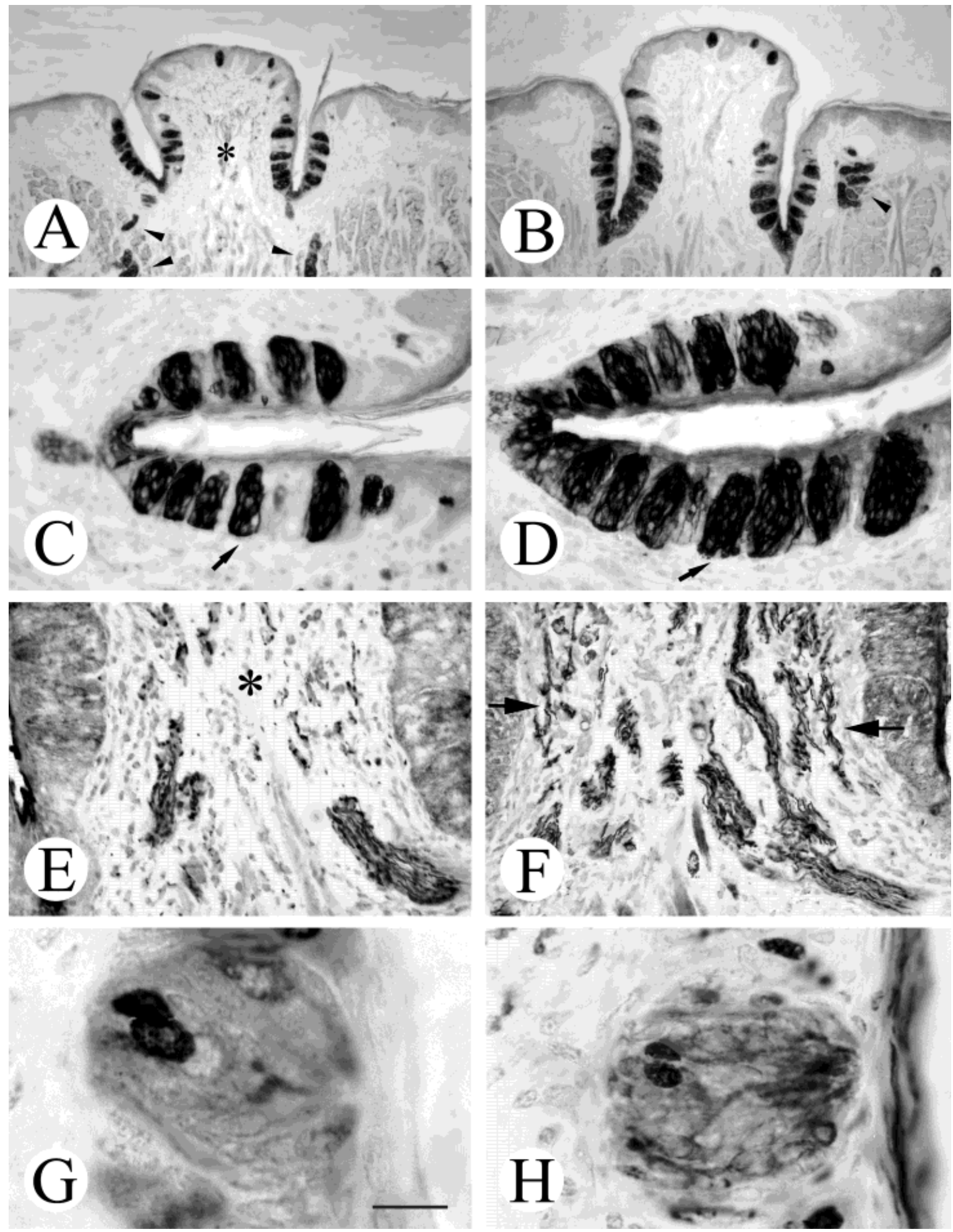

Fig. 3. A: A low-power photomicrograph of representative crosssections of a 7-month wild-type vallate shows that both vallate trenches are lined with gustatory epithelium that contains keratin 8-positive taste buds. Arrowheads indicate immunopositive salivary duct cells. An asterisk marks the core of the vallate papilla. B: A $b a x^{-1-}$ mouse has a larger than normal vallate papilla (aged 6 months). Arrowheads indicate keratin 8-positive salivary duct cells. C: Higher magnification of the right trench of the wild-type vallate in A. D: $b a x^{-1-}$ taste buds are larger. Arrows in C and D point to individual taste bud profiles, each of whose area is within $1 \%$ of the mean area of taste bud profiles from a 7-month wild-type and a 6-month $b_{a x}{ }^{-1-}$ vallate, respectively. E,F: In these vallate cross sections, dorsal is at the top, whereas the evenly stained gustatory epithelium is the gray margin on both the left and right sides of each

panel. E: For spatial orientation an asterisk has been placed in the position equivalent to the location of the asterisk in panel $\mathrm{A}$. The large, dark IXth nerve fascicle in the lower right is directed dorsally toward the center of the vallate connective tissue core of a 7-month wild-type mouse. A sliver of the left trench is evident as a white area at the far left. Both the primary (RMO-270) and secondary antibodies were at 1:200. F: In this comparable section through the core of a 6-month bax ${ }^{-1-}$ mouse vallate papilla, the IXth nerve fascicles are more abundant, invading the lateral aspects (arrows) as they extend dorsally. RMO-270, 1:200; secondary antibody, 1:500. G,H: BrdU staining labeled two nuclei in a $(\mathrm{G})$ wild-type taste bud and $(\mathrm{H})$ two nuclei in a $b a x^{-1-}$ taste bud 3 days after BrdU injection. Scale bar = $180 \mu \mathrm{m}$ in A,B; $55 \mu \mathrm{m}$ in C,D; $80 \mu \mathrm{m}$ in E,F; $10 \mu \mathrm{m}$ in G; $14 \mu \mathrm{m}$ in $\mathrm{H}$. 


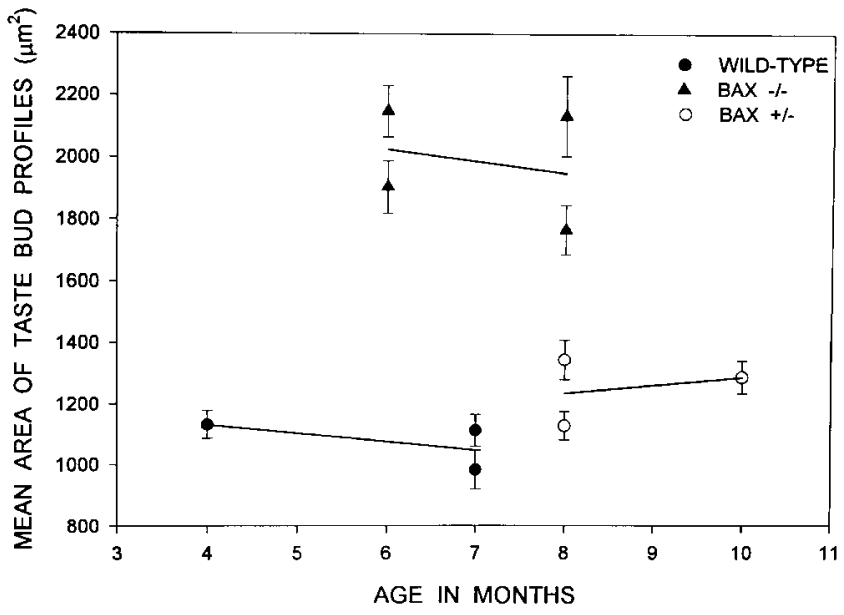

Fig. 4. For each of 10 mice the areas of taste bud profiles (mean \pm $1 \mathrm{SE}$ ) are shown as a function of age for wild-type, bax knockout, and bax heterozygous animals. The mean areas of taste bud profiles differ significantly with genotype (See results for statistical details.) In contrast, the regression lines for each genotype indicate no strong or consistent relationship with age. With genotype ignored, the mean areas of taste bud profiles were uncorrelated with age in the 10 mice $(\mathrm{r}=0.04$, regression line not shown $)$.

TABLE 3. Quantitative Effects of Bax Deficiency on Taste Cell Populations ${ }^{1}$

\begin{tabular}{|c|c|c|}
\hline & Wild-type & $b a x^{-1-}$ \\
\hline \multicolumn{3}{|l|}{ Mean number of nuclear profiles } \\
\hline Per taste bud profile & $17.44 \pm 0.5$ & $29.3 \pm 0.9^{*}$ \\
\hline Per $1,000 \mu \mathrm{m}^{2}$ of taste bud profile & 18.37 & 18.44 \\
\hline (Taste bud profiles examined) & $(61)$ & $(96)$ \\
\hline Ages of mice (months) & $7,7,7$ & $6,6,8,8$ \\
\hline \multicolumn{3}{|l|}{$\begin{array}{l}\text { Mean number of BrdU-positive } \\
\text { nuclear profiles }\end{array}$} \\
\hline Per taste bud profile & $1.25 \pm 0.2$ & $1.99 \pm 0.2^{*}$ \\
\hline Per $1,000 \mu \mathrm{m}^{2}$ of taste bud profile & 1.12 & 1.08 \\
\hline (Taste bud profiles examined) & $(48)$ & (89) \\
\hline Ages of mice (months) & 7,7 & 6,8 \\
\hline Percentage of intragemmal cell nuclei & 6.1 & 5.9 \\
\hline that were BrdU positive & $(1.12 \div 18.37)$ & $(1.08 \div 18.44)$ \\
\hline
\end{tabular}

${ }^{1}$ Values are means $\pm 1 \mathrm{SE}$ or means normalized for taste bud profile area.

$* P<0.001, t$-test.

taste bud of mean volume. As indicated by their normal density (number of nuclear profiles per $1,000 \mu \mathrm{m}^{2}$ of a taste bud profile), Bax-deficient taste buds were probably larger because they contained more, not bigger, intragemmal cells (Table 3 ).

\section{Gustatory innervation and vallate size in bax null mutant mice}

As determined in $b d n f, n t 3$, and trkB null mutant mice, the base of the vallate is a conduit for numerous BDNFdependent taste axons and NT3-dependent somatosensory axons (Nosrat et al., 1997; Zhang et al., 1997; Cooper and Oakley, 1998; Oakley, 1998; Oakley et al., 1998; Ringstedt et al., 1999). The survival of significantly more taste neurons in $b_{a x}{ }^{-1-}$ mice seems to have led to more profuse gustatory innervation of the vallate papilla. In $b a x^{-1-}$ mice, fascicles of the IXth nerve were more abundant and dispersed across more of the core of the vallate papilla in comparison with wild-type mice (Fig. 3E,F).

The 0.5-mm-wide mouse vallate papilla proper is framed by two trenches that are bracket shaped and ros-

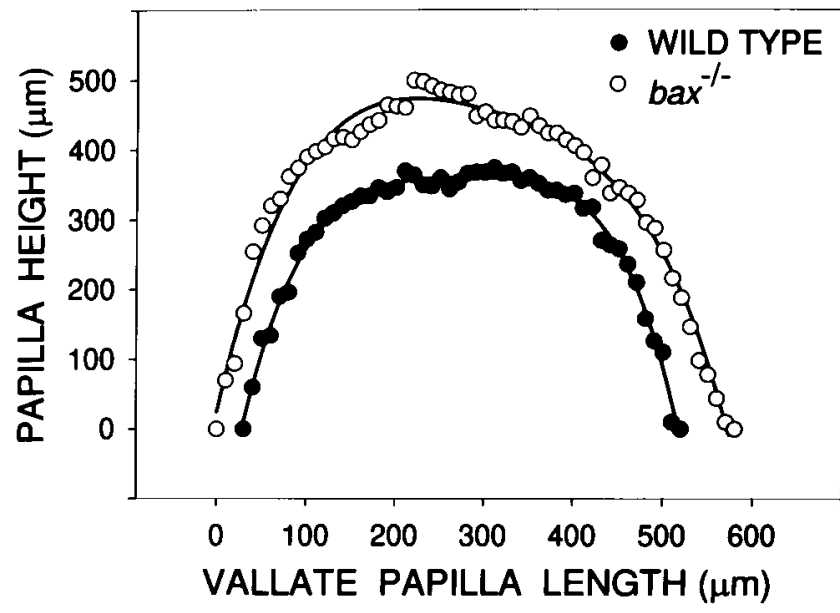

Fig. 5. The vallate papilla was rostrocaudally longer ( $\mathrm{x}$ axis) and higher (y axis) in the four bax null mutant mice than in the three 7-month-old wild-type mice. Each data point is the height of the vallate papilla as obtained from serial cross sections of the tongue taken at $10-\mu \mathrm{m}$ intervals. The fourth-order best-fit polynomial curves map out the shape of the vallate papilla as it would be seen in a lateral view.

trocaudally directed. Each trench is about $0.5 \mathrm{~mm}$ long and $0.5 \mathrm{~mm}$ deep. bax ${ }^{-1-}$ mice had longer and deeper trenches and therefore a larger vallate papilla (Figs. 3A,B, 5). Specifically, the vallate papilla was $26 \%$ longer in the four adult $\mathrm{bax}^{-1-}$ mice $(585 \pm 24 \mu \mathrm{m}$; mean \pm 1 SD) compared with three 7 -month wild-type mice $(465 \pm 34$ $\mu \mathrm{m} ; P<0.002$, t-test). The peak height of the vallate was significantly greater in the bax ${ }^{+\prime-}$ mice $(499 \pm 27 \mu \mathrm{m})$ than in the wild-type mice (390 $\pm 57 \mu \mathrm{m} ; P<0.02$, t-test). (For each mouse the peak height of the vallate papilla was calculated as the mean papilla height in the three sections that passed through the tallest portions of the vallate.) Compared with three P1 wild-type controls, the vallate papilla of three $\mathrm{P} 1 \mathrm{bax}^{-1-}$ mice was also about $25 \%$ wider, and its taste buds appeared to be larger and to contain more taste receptor cells.

\section{Taste receptor cell density and birth rate in adult bax null mutant mice}

Because Bax-deficient taste buds had a normal density of intragemmal cells, the size of their taste cells must have remained normal. Since newly formed taste cells can enter the adult mouse taste bud as soon as 1 day after cell birth (Zhang et al., 1995; Zeng and Oakley, 1999), it was anticipated that both $b_{a x}{ }^{-1-}$ and wild-type adult taste buds might have one or more BrdU-positive intragemmal cells 3 days after BrdU injection (Fig. 3G,H). Since bax ${ }^{-1-}$ taste buds were larger, they received more newborn taste cells (BrdU-positive nuclear profiles). When the incidence of BrdU-positive taste cells was normalized for the area of the taste bud profiles, the prevalence of BrdU-labeled nuclear profiles was indistinguishable between adult wildtype and $b a x^{-1-}$ mice (Table 3 ). In summary, although the intragemmal cells of $b a x^{-1-}$ taste buds were more numerous, they were normal in size and packing density and were replaced at normal birth rates. 


\section{Behavioral gustatory reactivity}

$b a x^{-1-}$ mice displayed a fourfold increase in the sucrose preference threshold (0.19 $\mathrm{M}$ for bax ${ }^{-1-}$ mice vs. $0.05 \mathrm{M}$ for wild-type mice; $n=4$ adult mice of similar weight). This raises the possibility that the supernumerary taste axons and taste cells had abnormal connections or were debilitated, as suggested for other types of neurons in bax $x^{-1-}$ mice (White et al., 1998). Further gustatory behavioral testing is warranted.

\section{DISCUSSION}

The gustatory phenotype of bax null mutant mice had several noteworthy features. An increase in vallate papilla innervation was accompanied by a $25 \%$ increase in vallate papilla length and height as well as an increase of more than twofold in the mean number of cells per taste bud. The 1.3-fold increase in cells per taste bud profile in $b a x^{+/-}$mice suggests a gene dosage effect. The Caspase-2 immunoreactivity of $b a x^{-1-}$ taste receptor cells was severely attenuated. Consideration of these gustatory changes in $b a x^{-1-}$ mice within the context of the coexpression of Bax and Caspase- 2 in aged wild-type taste cells suggested two topics for the discussion that follows: taste cell death components and the enhancement of taste organ development.

\section{Components of the death pathway in taste cell homeostasis}

Taste cells have a death pathway that differs from keratinocytes. By extruding its nucleus and subsequently shedding its cellular husk, a keratinocyte's death differs from conventional apoptosis that employs nuclear fragmentation, phagocytosis of cell debris, and other events common to most programmed cell death, including the death of taste cells (Takeda et al., 1996; Gandarillas et al., 1999). There is scant evidence for p53 or Bax involvement in normal keratinocyte death (cf. Spandau, 1994). Furthermore, it remains to be determined whether Caspase-2 is important in keratinocyte death (Takahashi et al., 1998; Weil et al., 1999). The caspases that degrade the cytokeratins special to taste cells may differ from caspases that degrade the wholly different set of cytokeratins in neighboring squamous, epithelial cells (Knapp et al., 1995; Zhang and Oakley, 1996; Caulin et al., 1997). For these reasons, one anticipates that taste cells and keratinocytes will be shown to use different death pathways.

Dying neurons may have more steps in common with dying taste cells. Since neurons and taste receptor cells share several vital properties, their death pathways might also overlap. Apoptotic, mature taste cells coexpress p53, (Zeng and Oakley, 1999), Bax, and Caspase-2. Developing neurons use Bax as a death factor in PCD (White et al., 1998). Apoptosis of NGF-deprived sympathetic neurons requires both Bax and Caspase-2 (Deckwerth et al., 1996; Troy et al., 1997). p53 appears to participate in the apoptosis of some neurons and oligodendrocytes (Eizenburg et al., 1996; Aloyz et al., 1998). However, p53 in the brain is mainly associated with dividing and differentiating neurons that do not overlap those expressing Bax (van Lookeren Campagne and Gill, 1998). Each of the following neuronal genes can be upregulated by cerebral ischemia: p53 (Li et al., 1994), bax (Krajewski et al., 1995), and caspase-2 (Asahi et al., 1997; Kinoshita et al., 1997; Kitagawa et al., 1998). As these examples indicate, some among the many types of neurons can express at least one or two of these three death factors. However, it has not been shown that the triad p53, Bax, and Caspase-2 is evoked during any individual brain neuron's death as it is in taste receptor cells.

The linkage of Bax to Caspase-2 and a putative taste cell death pathway. The present search for a taste cellassociated caspase was prompted by four indications that p53 and bax are part of an apoptotic pathway of mouse taste receptor cells. Lingual p53 and Bax were 1) restricted to intragemmal cells; 2 ) each first detected at P1; 3) coexpressed in $81 \%$ of P5 immunoreactive vallate taste cells; and 4) associated with cell death by the apoptotic morphology of some immunopositive receptor cells (Zeng and Oakley, 1999).

Caspase-2 is implicated in taste cell death by its baxdependent coexpression and by the apoptotic morphological defects of some Caspase-2 immunopositive taste cells. The substantial loss of gustatory Caspase-2 expression in bax null mutant mice places Caspase-2 after Bax in the gustatory death pathway. p53 can function as a transcription factor for Bax in human cells (Miyashita and Reed, 1995; Aloyz et al., 1998), although p53 appears not to regulate Bax in some kinds of murine cells (Schmidt et al., 1999), nor is p53 required for Bax expression in vallate taste receptor cells (Zeng and Oakley, 1999). Nonetheless, the close association of p53 with Bax and Caspase- 2 expression is consistent with a role for p53 as a homeostatic death factor that contributes to the demise of aged taste cells.

Modeling the time course and duration of a triad of taste cell death factors. Because neonatal vallate taste receptor cells are in the process of differentiating (Hosley and Oakley, 1987; Cooper and Oakley, 1998), few of their intragemmal cells are as old as 9 days-the mean taste cell life span. This could explain why less than $1 \%$ of the taste cells were Bax or p53 positive at P5 and at P7 (Zeng and Oakley, 1999). Since taste cell turnover in neonates had not yet reached a steady state, we could not estimate the duration of Bax expression from the percentage of Bax-positive cells. Instead, the durations of death factors at P7 were scaled by assuming that Bax expression would last as long as it did in adults (22.5 hours). The p53, Bax, and Caspase-2 gustatory temporal expression patterns in adults were similar to those in P7 mice, except that p53 and Caspase-2 were typically contemporaneously expressed in P7 taste cells whereas p53 began about 15 hours earlier in adults (Fig. 6). The adult difference in the timing of p53 and Bax expression and the failure of p53 null mutation to eliminate bax expression (Zeng and Oakley, 1999) suggest that any p53 upregulation of gustatory bax is redundant, or indirect, or only effective after accumulating a high concentration of p53, thereby delaying Bax expression.

p53, Bax, and Caspase-2 were associated with dying taste cells since 1) there was a higher incidence of apoptotic morphological defects in immunopositive cells; 2) the percentages of taste cells immunopositive for these factors $(9-11 \%)$ were similar to the $8 \%$ of taste cells positive for terminal deoxy nucleotidyl transferase-mediated dUTP biotin nick end labeling (TUNEL; Zeng and Oakley, 1999); and 3 ) at P7 the pronounced coexpression of Bax with p53, and Bax with Caspase-2, indicates that all three factors 


\section{MODEL OF DEATH FACTOR DURATIONS IN TASTE CELLS $($ p53 $\rightarrow$ BAX $\rightarrow$ CASPASE-2 $\rightarrow$ MORPHOLOGICAL BREAKDOWN)}

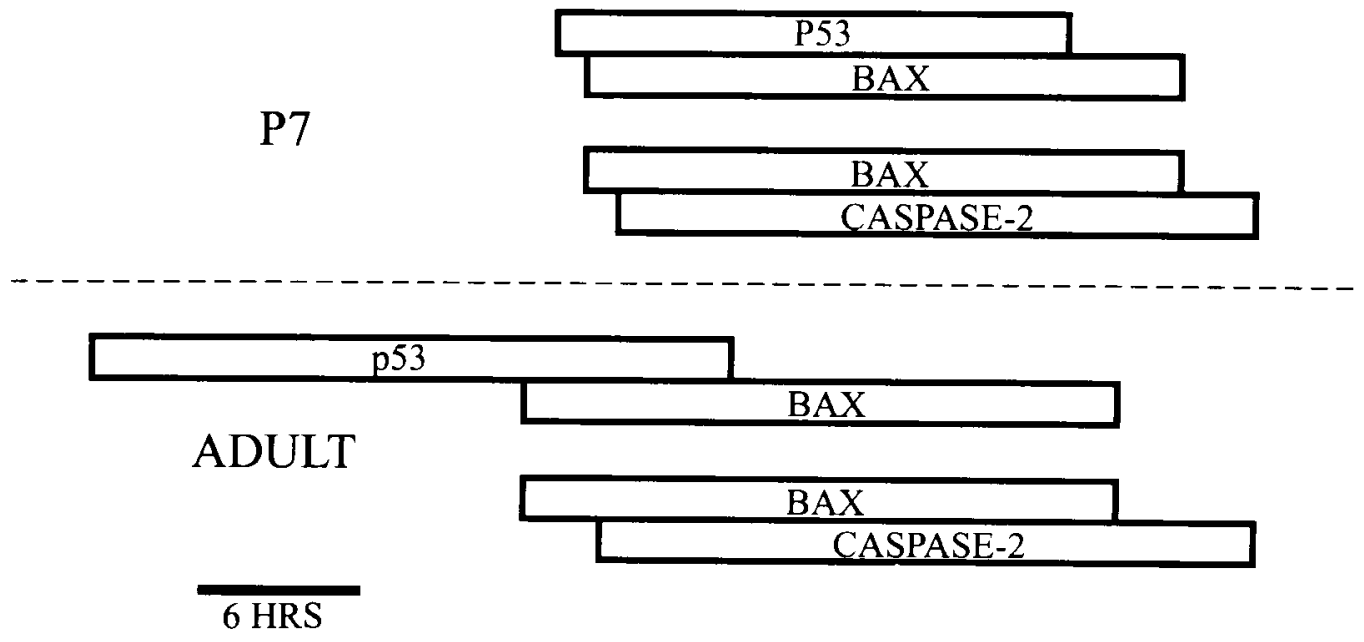

Fig. 6. The four pairs of duration bars indicate the time courses of p53, Bax, and Caspase-2 immunoexpression in P7 and adult vallate taste buds. The extent of overlap of the Bax and p53 bars, and of the Bax and Caspase-2 bars, depicts the temporal overlap in taste cell immunoexpression, as calculated from the incidence of double labeling. For adults the average expression durations (bar lengths) were calculated as follows from the percentages of cells stained in the single-staining experiments (Table 1 and Zeng and Oakley, 1999). With a taste cell life span of 9 days (Takeda, 1979), an average of $11.1 \%$ of taste cells should die each day in adults (lower half of the diagram). Hence, by staining $11 \%$ of the taste cells, Caspase- 2 expression should have lasted an average of 24 hours; by staining $11.4 \%$ of the cells, p53 should have lasted 25 hours; and by staining $10.3 \%$ of the cells, Bax should have lasted 22.5 hours. The percentages of cells

were characteristically expressed in the same cells. Cell death was mainly restricted to older cells, given that Bax immunostaining in adults was absent from taste receptor cells younger than 5 days (Zeng and Oakley, 1999). Furthermore, at P7, when old taste receptor cells were still uncommon, less than $1 \%$ of taste cells were immunopositive for p53 or Bbax (Zeng and Oakley, 1999).

\section{Gain-of-function: the addition of taste neurons is associated with taste organ enhancement}

Vallate population dynamics. When BrdU-positive cells were normalized as a percentage of all cells per taste bud profile, it was evident that $b_{a x} x^{-1}$ and wild-type adult taste buds had equivalent rates of taste cell birth. These birth rates must have been in balance with death rates, since, in adults, the mean size of wild-type and $b a x^{-1-}$ taste buds remained stable for months. Hence, it is probable that taste cell birth rate, death rate, and longevity were similar in adult $b a x^{-/-}$and wild-type taste buds. Characteristic of healthy, renewing epithelia, such a homeostatic balance between taste cell births and deaths in adults points to an earlier developmental and maturational period as the time when the taste cell population markedly increased before reaching stability in adulthood. Already by $\mathrm{P} 1, \mathrm{bax}^{-/-}$mice had developed a larger vallate stained by p53, or Bax, or Caspase-2 were reliable, as indicated by close agreement between independent calculations from single- and double-staining experiments in adults. Specifically, there was less than a $2 \%$ difference in the ratio of Caspase- 2 to Bax durations calculated from the percentages of immunopositive cells in doublestaining experiments (1.10; Table 2), compared with a pair of singlestaining experiments (1.07; Zeng and Oakley, 1999). Similarly, there was less than a $2 \%$ difference in the ratio of p53 to Bax durations when the ratio was calculated from the percentage of reactive taste cells in two single- (1.10) vs. one double-staining experiment (1.08; Zeng and Oakley, 1999). Data for P7: to generate the P7 portion of the diagram, we assumed the adult values of a 9-day life span and a 22.5-hour Bax duration (see text).

papilla whose taste buds appeared to be enlarged with more taste receptor cells.

A probable role for increased innervation in augmenting vallate size and taste cell abundance. By sparing sensory neurons from normal developmental PCD, Bax deficiency appears to have increased the number of IXth nerve gustatory axons, much as Bax deficiency increased the number of Vth nerve somatosensory neurons and VIIIth nerve vestibular neurons (Deckwerth et al., 1996; Shindler et al., 1997; White et al., 1998). The increase in gustatory neurons within the Bax-deficient vallate resembles a similar increase in the Bax-deficient retina whose ganglion cell neurons doubled. However, because photoreceptor development is independent of innervation, the numbers of rod and cone receptor cells did not increase (Mosinger et al., 1998). In contrast, bax ${ }^{-1-}$ taste receptor cells increased more than twofold, above and beyond the previously demonstrated normal neonatal addition of taste cells (Hosley and Oakley, 1987). It is during the neonatal period that taste bud size becomes positively correlated with the number of innervating axons (Krimm and Hill, 1998). A twofold increase in the number of petrosal (IXth nerve) and nodose ganglia neurons was linked to a developmental excess of BDNF that may have rescued sensory neurons from PCD (Ringstedt et al., 1999). Postnatally, gustatory innervation is not only necessary for the 
development of most taste buds (Hosley et al., 1987a,b), but also appears essential for taste cell competence. Temporary denervation at P3 permanently eliminates the competence of the subsequently reinnervated vallate epithelium to form taste cells (Oakley, 1993). In the absence of timely innervation, gustatory precursor cells apparently die or alter their function.

We hypothesized that conditions that increased embryonic gustatory innervation should enhance gustatory development, since an embryonic reduction in gustatory innervation quantitatively impairs the development of the gustatory organ (Oakley, 1998; Oakley et al., 1998). In $b a x^{-1-}$ mice, the perinatal augmentation of taste organ development is probably a result of the greater innervation caused by diminished gustatory neuronal PCD. We also evaluated the contending hypothesis that Bax deficiency directly increased the number of gustatory precursor cells able to survive epithelial PCD. In this alternative to neural influences, perinatal wild-type mice should have Bax-positive, dying taste cells at least by the first postnatal week when the majority of immature and mature vallate taste buds arise (Hosley and Oakley, 1987; Oakley et al., 1991; Cooper and Oakley, 1998). However, within the wild-type vallate papilla there were no Bax-positive cells at E15, E17, or P0. Moreover, from P1 to P7, Bax-positive taste cells were infrequent and were usually differentiated (elongated) and therefore not the hypothesized dying gustatory precursor cells (present results; Zeng and Oakley, 1999).

It remains possible that a fleeting embryonic burst of Bax-mediated taste cell death escaped our examination. However, it is more likely that any PCD of taste cell precursors was independent of Bax. Accordingly, we suggest that Bax deficiency acted indirectly by sustaining more gustatory neurons whose trophic support in turn sustained a larger pool of gustatory precursor cells. It remains to be determined whether other innervationdependent sense organs, like muscle spindles, are also more abundant in $b a x^{-1-}$ mice.

\section{SUMMARY}

By exploiting the taste bud as a quantifiable packet of simple epithelial cells, we have been able to inquire into the development of a renewing epithelium. To understand life and death pathways, one must identify the controlling factors and elucidate their mechanisms of action. We, and others, have shown that gustatory innervation is essential for taste bud development (reviewed in Oakley, 1998; Liebl et al., 1999; Mistretta et al., 1999; Ringstedt et al., 1999). By exploiting the increased survival of Baxdeficient taste neurons, the present study examined the vallate papilla in a gain-of-innervation model. The close parallel with multiple demonstrations that link decreased embryonic innervation to a smaller gustatory epithelium and fewer taste cells make it likely that the increased gustatory innervation within the bax $x^{-1-}$ vallate papilla contributed to an increase in both the papilla's size and the number of its taste cells (Oakley et al., 1998).

In contrast to a century of interest in the neural control of taste bud development, it is only recently that the death pathway underlying taste cell turnover has been approached (Zeng and Oakley, 1999). Taste cell apoptotic morphological breakdown is proposed to involve a set of three death proteins, p53, Bax, and Caspase-2, acting as members of the default death pathway. That none of these factors is required to eliminate taste cells implies redundant death pathways whose combined intricacies may make the regulation of taste cells more complex during death than during development.

\section{ACKNOWLEDGMENTS}

We thank Anne Lawton, Michael McCoy, and Hanshi Sun for their assistance.

\section{LITERATURE CITED}

Adams JM, Corey S. 1998. The Bcl-2 protein family: arbiters of cell survival. Science 281:1322-1326.

Aloyz RS, Bamji SX, Pozniak CD, Toma JG, Atwal J, Kaplan DR, Miller FD. 1998. p53 is essential for developmental neuron death as regulated by the TrkA and p75 neurotrophin receptors. J Cell Biol 143:16911703.

Asahi M, Hoshimaru M, Uemura Y, Tokime T, Kojima M, Ohtsuka T, Matsuura M, Aoki T, Shibahara K, Kikuchi H. 1997. Expression of interleukin-1 beta converting enzyme gene family and bcl-2 gene family in the rat brain following permanent occlusion of the middle cerebral artery. J Cereb Blood Flow Metab 17:11-18.

Beidler LM, Smallman RL. 1965. Renewal of cells within taste buds. J Cell Biol 27:263-272.

Boise LH, Gonzalez GM, Postern CE, Ding L, Lindsten T, Turka LA, Mao X, Nuñez G, Thompson CB. 1993. Bcl-x, a bcl-2-related gene that functions as a dominant regulator of apoptotic cell death. Cell 74:597608.

Caulin C, Salvesen GS, Oshima RG. 1997. Caspase cleavage of keratin 18 and reorganization of intermediate filaments during epithelial cell apoptosis. J Cell Biol 138:1379-1394.

Chittenden T, Harrington EA, O'Connor R, Flemington C, Lutz RJ, Evan GI, Guild BC. 1995. Induction of apoptosis by the bcl-2 homolog bak. Nature 374:733-736.

Cooper D, Oakley B. 1998. Functional redundancy and gustatory development in bdnf null mutant mice. Brain Res Dev Brain Res 105:79-84.

Deckwerth TL, Elliott LL, Knudson CM, Johnson EM, Snider WD, Korsmeyer SJ. 1996. Bax is required for neuronal death after trophic factor deprivation and during development. Neuron 17:401-411.

Eizenberg O, Faber-Elman A, Gottlieb E, Oren M, Rotter V, Schwartz M. 1996. p53 plays a regulatory role in differentiation and apoptosis of central nervous system-associated cells. Mol Cell Biol 16:5178-5185.

Ellis RE, Yuan JY, Horvitz HR. 1991. Mechanisms and functions of cell death. Annu Rev Cell Biol 7:663-698.

Farbman AI. 1980. Renewal of taste bud cells in rat circumvallate papillae. Cell Tissue Kinet 13:349-357.

Farmer G, Bargonetti J, Zhu H, Friedman P, Prywes R, Prives C. 1992 Wild-type p53 activates transcription in vitro. Nature 358:83-86.

Fritzsch B, Saral PA, Barbacid, M, Silos-Santiago I. 1997. Mice with a targeted disruption of the neurotrophin receptor trkB lose their gustatory ganglion cells early but do develop taste buds. Int J Dev Neurosci 15:563-576.

Gandarillas A, Goldsmith LA, Gschmeisser S, Leigh IM, Watt FM. 1999 Evidence that apoptosis and terminal differentiation of epidermal keratinocytes are distinct processes. Exp Derm 8:71-79.

Haake AR, Polakowska RR. 1993. Cell death by apoptosis in epidermal biology. J Invest Dermatol 161:107-112.

Hosley MA, Oakley B. 1987. Postnatal development of the vallate papillae and taste buds in rats. Anat Rec 218:216-222

Hosley MA, Hughes SE, Oakley B. 1987a. Neural induction of taste buds. J Comp Neurol 260:224-232.

Hosley MA, Hughes SE, Morton LL, Oakley B. 1987b. A sensitive period for the neural induction of taste buds. J Neurosci 7:2075-2080.

Kaufmann SH, Desnoyers S, Ottaviano Y, Davidson NE, Poirier GG. 1993. Specific proteolytic cleavage of poly (ADP-ribose) polymerase: an early marker of chemotherapy-induced apoptosis. Cancer Res 53:3976-3985.

Kiefer MC, Braucer MJ, Powers VC, Wu JJ, Umansky SR, Tomei LD, Barr PJ. 1995. Modulation of apoptosis by the widely distributed Bcl-2 homologue Bak. Nature 374:736-739.

Kinoshita M, Tomimoto H, Kinoshita A, Kumar S, Noda M. 1997. Up- 
regulation of the Nedd2 gene encoding an ICE/Ced-3-like cysteine protease in the gerbil brain after transient global ischemia. J Cereb Blood Flow Metab 17:507-514.

Kitagawa H, Hayashi T, Mitsumoto Y, Koga N, Itoyama Y, Abe K. 1998. Reduction of ischemic brain injury by topical application of glial cell line-derived neurotrophic factor after permanent middle cerebral artery occlusion in rats. Stroke 29:1417-1422.

Knapp L, Lawton A, Oakley B, Wong L, Zhang C. 1995. Keratins as markers of differentiated taste cells. Differentiation 58:341-349.

Knudson CM, Tung KSK, Tolurtellotte WG, Brown GAJ, Korsmeyer SJ. 1995. Bax-deficient mice with lymphoid hyperplasia and male germ cell death. Science 270:96-99.

Krajewski S, Krajewska M, Shabaik A, Miyashita T, Wang HG, Reed JC. 1994. Immunohistochemical determination of in vivo distribution of Bax, a dominant inhibitor of Bcl-2. Am J Pathol 45:1323-1336.

Krajewski S, Mai JK, Krajewska M, Sikorska M, Mossakowski MJ, Reed JC. 1995. Upregulation of Bax protein levels in neurons following cerebral ischemia. J Neurosci 15:6364-6376.

Krimm R, Hill D. 1998. Innervation of single fungiform taste buds during development in the rat. J Comp Neurol 398: 13-24.

Kumar S, Tomooka Y, Noda M. 1992. Identification of a set of genes with developmentally down-regulated expression in the mouse brain. Biochem Biophys Res Commun 185:1155-1161.

Kumar S, Kinoshita M, Noda M, Copeland NG, Jenkins NA. 1994. Induction of apoptosis by the mouse Nedd2 gene, which encodes a protein similar to the product of the Caenorhabditis elegans cell death gene

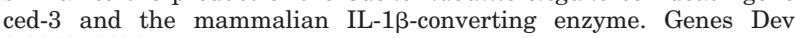
8:1613-1626.

Lazebnik YA, Takahashi A, Moir R, Goldman R, Poirier GG, Kaufmann SH. 1995. Studies of the lamin proteinase reveal multiple parallel biochemical pathways during apoptotic execution. Proc Natl Acad Sci USA 92:9042-9046.

Li H, Yaun J. 1999. Deciphering the pathways of life and death. Curr Opin Cell Biol 11:261-266.

Li Y, Chopp M, Zhang ZG, Zaloga C, Niewensuis L, Gautam S. 1994. Induction of DNA fragmentation after 10 to 120 minutes of focal cerebral ischemia in rats. Stroke 25:849-855.

Liebl DH, Mbiene JP, Parada LF. 1999. NT4/5 mutant mice have deficiency in gustatory papillae and taste bud formation. Dev Biol 213:378-389.

McCall CA, Cohen JJ. 1991. Programmed cell death in terminally differentiating keratinocytes: role of endogenous endonuclease. J Invest Dermatol 97:111-114.

Mistretta CM, Goosens KA, Farinas I, Reichardt LF. 1999. Alterations in size, number and morphology of gustatory papillae and taste buds in BDNF null mutant mice demonstrate neural dependence of developing taste organs. J Comp Neurol 409:13-24.

Miyashita T, Reed JC. 1995. Tumor suppressor p53 is a direct transcriptional activator of human bax gene. Cell 80:293-299.

Miyashita T, Krajewski S, Krajewska M, Wang HG, Lin HK, Liebermann DA, Hoffman B, Reed JC. 1994. Tumor suppressor p53 is a regulator of bcl-2 and bax gene expression in vitro and in vivo. Oncogene 9:17991805.

Morris-Wiman J, Basco E Du Y. 1999. The effects of $\beta$-bungarotoxin on the morphogenesis of taste papillae and taste buds in the mouse. Chem Senses 24:7-17.

Mosinger OJ, Deckwerth TL, Knudson CM, Korsmeyer SJ. 1998. Suppression of developmental retinal cell death but not of photoreceptor degeneration in Bax-deficient mice. Invest Ophthal Vis Sci 39:1713-1720.

Neamati N, Fernandez A, Wright S, Kiefer J, McConkey DJ. 1994. Degradation of lamin B1 precedes oligonucleosomal DNA fragmentation in apoptotic thymocytes and isolated thymocyte nuclei. J Immunol 154: 1693-1700.

Nosrat CA, Blomlof J, ElShamy WM, Ernfors P, Olson L. 1997. Lingual deficits in BDNF and NT3 mutant mice leading to gustatory and somatosensory disturbances, respectively. Development 124:13331342 .

Nuñez G, Clarke MF. 1994. The Bcl-2 family of proteins: regulators of cell death and survival. Trends Cell Biol 4:399-403.

Oakley B. 1993. The gustatory competence of the lingual epithelium requires neonatal innervation. Brain Res Dev Brain Res 72:259-264.

Oakley B. 1998. Taste neurons have multiple inductive roles in mammalian gustatory development. Ann N Y Acad Sci 855:50-57.

Oakley B, LaBelle DE, Riley RA, Wilson K, Li LW. 1991. The rate and locus of development of rat vallate taste buds. Brain Res Dev Brain Res 58:215-221.

Oakley B, Brandemihl A, Cooper D, Lau D, Lawton A, Zhang C. 1998. The morphogenesis of mouse vallate gustatory epithelium and taste buds requires BDNF-dependent taste neurons. Brain Res Dev Brain Res 105:85-96.

Polakowska RR, Piacentini M, Bartlett R, Goldsmith LA, Haake AR. 1994 Apoptosis in human skin development: morphogenesis, periderm, and stem cells. Dev Dyn 199:176-188.

Reed JC. 1997. Double identity for proteins of the Bcl-2 family. Nature 387:773-776

Ringstedt T, Ibanez CF, Nosrat CA. 1999. Role of brain-derived neurotrophic factor in target invasion in the gustatory system. J Neurosci 19:3507-3518.

Schmidt T, Körner, K, Karsunky, H, Korsmeyer S, Müller R, Möröy T. 1999. The activity of murine Bax promoter is regulated by $\mathrm{Sp} 1 / 3$ and E-box binding proteins but not by p53. Cell Death Diff 6:873-882.

Selvakumaran M, Lin HK, Miyashita T, Wang HG, Krajewski S, Reed JC, Hoffman B, Liebermann D. 1994. Immediate early up-regulation of bax expression by p53 but not TGF- $\beta 1$ : a paradigm for distinct apoptotic pathways. Oncogene 9:1791-1798.

Shindler KS, Latham CB, Roth KA. 1997. Bax deficiency prevents the increased cell death of immature neurons in bcl-x-deficient mice. J Neurosci 17:3112-3119.

Spandau DF. 1994. Distinct conformations of p53 are observed at different stages of keratinocyte differentiation. Oncogene 9:1861-1868.

Stone LM, Finger TE, Tam PPL, Tan SS. 1995. Taste receptor cells arise from local epithelium, not neurogenic ectoderm. Proc Natl Acad Sci USA 92:1916-1920.

Susin SA, Lorenzo HK, Zamzami N, Marzo I, Brenner C, Larochette N, Prévost MC, Alxari PM, Kroemer G. 1999. Mitochondrial release of caspase-2 and -9 during the apoptotic process. J Exp Med 189:381-394.

Takahashi T, Ogo M, Hibino T. 1998. Partial purification and characterization of two distinct types of caspases from human epidermis. J Invest Dermatol 111:367-373.

Takeda M. 1979. Tritiated thymidine autoradiographic study of taste buds in the mouse. Acta Anat Nippon 54:230-231.

Takeda M, Suzuki Y, Obara N, Nagai Y. 1996. Apoptosis in mouse taste buds after denervation. Cell Tissue Res 286:55-62.

Tamada Y, Takama H, Kitamura T, Yokochi K, Nitta Y, Ikeya T, Matsumoto Y. 1994. Identification of programmed cell death in normal human skin tissues by using specific labeling of fragmented DNA. Br J Dermatol 131:521-524.

Thornberry NA, Lazebnik Y. 1998. Caspases: enemies within. Science 281:1312-1316.

Troy CM, Stefanis L, Greene LA, Shelanski ML. 1997. Nedd2 is required for apoptosis after trophic factor withdrawal, but not superoxide dismutase (SOD1) downregulation, in sympathetic neurons and PC12 cells. J Neurosci 17:1911-1918.

van Lookeren Campagne M, Gill R. 1998. Tumor-suppressor p53 is expressed in proliferating and newly formed neurons of the embryonic and postnatal rat brain: comparison with expression of the cell cycle regulators $\mathrm{p} 21^{\text {Waf1/Cip } 1}, \mathrm{p} 27^{\text {Kip } 1}$, p5 $7^{\text {Kip } 2}, \mathrm{p} 16^{\text {Ink-4a }}$, cyclin $\mathrm{G} 1$, and the proto-oncogene Bax. J Comp Neurol 397:181-198.

Weil M, Raff MC, Braga VMM. 1999. Caspase activation in the terminal differentiation of human epidermal keratinocytes. Curr Biol 9:361364.

White FA, Keller-Peck CR, Knudson CM, Korsmeyer SJ, Snider WD. 1998. Widespread elimination of naturally occurring neuronal death in Baxdeficient mice. J Neurosci 18:1428-1439.

Yin C, Knudson CM, Korsmeyer SJ, Van Dyke T. 1997. Bax suppresses tumorigenesis and stimulates apoptosis in vivo. Nature 385:637-640.

Zeng Q, Oakley B. 1999. p53 and Bax: putative death factors in taste cell turnover. J Comp Neurol 413:168-180.

Zhang C, Oakley B. 1996. The distribution and origin of keratin 20containing taste buds in rat and human. Differentiation 61:121-128.

Zhang C, Cotter M, Lawton A, Oakley B, Wong L, Zeng Q. 1995. Keratin 18 is associated with a subset of older taste cells in the rat. Differentiation 59:155-162.

Zhang C, Brandemihl A, Lau D, Lawton A, Oakley B. 1997. BDNF is required for the normal development of taste neurons in vivo. Neuroreport 8:1013-1017. 